OPEN ACCESS

Edited by:

Daniel Franco,

Centro Tecnologico de la Carne, Spain

Reviewed by:

Erick Saldaña,

University of Moquegua, Peru

Márcio Vargas Ramella,

Santa Catarina State University, Brazi

*Correspondence:

Paulo Cezar Bastianello Campagnol paulo.campagno@@ufsm.br

Specialty section:

This article was submitted to

Product Quality,

a section of the journal

Frontiers in Animal Science

Received: 22 January 2021

Accepted: 16 April 2021

Published: 13 May 2021

Citation:

dos Santos BA, Cichoski AJ and Campagnol PCB (2021) Inulin, KCL, and Flavor Enhancers: An Efficient

Combination to Produce Prebiotic and

Low-Sodium Burgers.

Front. Anim. Sci. 2:657252.

doi: 10.3389/fanim.2021.657252

\section{Inulin, KCL, and Flavor Enhancers: An Efficient Combination to Produce Prebiotic and Low-Sodium Burgers}

\author{
Bibiana Alves dos Santos, Alexandre José Cichoski and \\ Paulo Cezar Bastianello Campagnol* \\ Food Science and Technology, Universidade Federal de Santa Maria, Santa Maria, Brazil
}

In this study, prebiotic and low-sodium burgers were produced. In the first experiment, burgers were elaborated with 0, 3, 6, 9, and 12\% inulin. The addition of up to $9 \%$ inulin did not affect the sensory quality, increased yield and reduced shrinkage. Thus, in the second experiment, prebiotic burgers were produced with $9 \%$ inulin and a sodium reformulation was performed by replacing $60 \% \mathrm{NaCl}$ with $\mathrm{KCl}$ and adding monosodium glutamate (MG) and/or liquid smoke (LS). The replacement of $\mathrm{NaCl}$ for $\mathrm{KCl}$ impaired the sensory quality of the burgers. The isolated or combined addition of MG and LS reduced the sensory defects caused by $\mathrm{KCl}$. Thus, prebiotic and low-sodium burgers with high technological and sensory quality can be produced using $9 \%$ inulin, $1 \% \mathrm{NaCl}, 1.5 \% \mathrm{KCl}, 0.2 \% \mathrm{MG}$, and $0.1 \%$ LS.

Keywords: healthier meat products, monosodium glutamate, liquid smoke, technological quality, sensory quality

\section{INTRODUCTION}

The consumption of foods rich in bioactive compounds is an excellent strategy to strengthen the immune system and improve the quality of life of the population. This fact has caused an increase in the world demand for healthier foods and challenged the meat industry to develop differentiated products. The reformulation through the substitution of harmful compounds to health and the incorporation of bioactive compounds, such as prebiotic fibers, is an efficient approach to produce healthier meat products.

In addition to improving nutritional quality, fibers increase water retention (do Amaral et al., 2015; Henning et al., 2016; Han and Bertram, 2017) which can be useful to improve the technological and sensory quality of low -fat and/or low-sodium meat products. In this context, inulin has been used successfully as a fat substitute in meat products (Âlvarez and Barbut, 2013; Keenan et al., 2014a). Inulin is considered a prebiotic fiber because it is not digestible and selectively stimulates the multiplication and activity of beneficial intestinal bacteria (Saad et al., 2011). Thus, inulin intake improves the immune system and also reduces the risk of diseases such as colon cancer and osteoporosis (Wan et al., 2020; Bakirhan and Karabudak, 2021).

Reducing the sodium content is another way of giving healthier properties to meat products, since the correlation between excessive sodium intake and the occurrence of cardiovascular diseases is well-documented (Cappuccio et al., 2019). $\mathrm{NaCl}$ replacement by $\mathrm{KCl}$ is one of the most efficient strategies to decrease the sodium content of meat products (Pateiro et al., 2021). However, sensory quality can be impaired depending on the type of meat product and the level of substitution (Saldaña et al., 2021). Thus, the use of flavor enhancers in conjunction with $\mathrm{KCl}$ is an approach that should be researched to improve the sensory quality of low-sodium meat products. 
Monosodium glutamate (MG) and liquid smoke (LS) are flavor enhancers that have already been used successfully in isolation to compensate for sensory defects caused by $\mathrm{KCl}$ in meat products (Dos Santos et al., 2014; Santos Alves et al., 2017). However, the combined use of both compounds is still little explored. Thus, in the first part of this study the effect of adding $0,3,6,9$, and $12 \%$ inulin on the technological and sensory quality of burgers was evaluated (Experiment 1). Subsequently, prebiotic burgers were produced with $9 \%$ inulin and a sodium reformulation was performed by replacing $60 \% \mathrm{NaCl}$ with $\mathrm{KCl}$ and adding $\mathrm{MG}$ and LS. The effect of this sodium reformulation on the sensory quality of burgers was evaluated (Experiment 2).

\section{MATERIALS AND METHODS}

\section{Treatments and Processing of Burgers}

In Experiment 1 burgers were produced with the addition of 0 , $3,6,9$, and $12 \%$ inulin (Orafti ${ }^{\circledR} \mathrm{HP}$, Beneo-Orafti, São Paulo, SP). In Experiment 2, burgers were produced with $9 \%$ inulin and $60 \%$ replacement of $\mathrm{NaCl}$ by $\mathrm{KCl}$. In addition, $\mathrm{MG}$ and LS were also added (Table 1). Beef was ground using a $3 \mathrm{~mm}$ plate and mixed with the remaining ingredients. Burgers $(60 \mathrm{~g})$ with $11 \mathrm{~cm}$ diameter and $2.5 \mathrm{~cm}$ thickness were manufactured using conventional burger-maker. The burgers were immediately frozen and stored at $-18^{\circ} \mathrm{C}$ until the time of analysis.

\section{Chemical Composition}

The chemical composition of the raw burgers was determined in triplicate using three samples for each treatment. The moisture content was determined by drying in an oven at $105 \pm 2{ }^{\circ} \mathrm{C}$; the nitrogen content was determined by the Kjeldahl method and the protein content estimated by multiplying the nitrogen content by 6.25 ; the fat content was determined by the Soxhlet method using petroleum ether, and the ash content was determined by incineration in a muffle furnace at $550^{\circ} \mathrm{C}$ (AOAC, 2005).

\section{Cooking Properties}

Three burgers of each treatment were cooked in a hot plate $\left(150^{\circ} \mathrm{C}\right)$, until a core temperature of $72^{\circ} \mathrm{C}$. The samples were cooled at room temperature $\left(25^{\circ} \mathrm{C}\right)$ before weighing. Yield was determined by weighing each burger before and after cooking, which was defined as the cooked weight divided by the uncooked weight, and then multiplied by 100 (Murphy et al., 1975). The shrinkage was calculated using the following equation: \% Shrinkage $=[($ Diameter of the raw sample - diameter of the cooked sample) / diameter of the raw sample) $] \times 100$ (Berry, 1992).

\section{Instrumental Color}

The color of raw burgers was measured using a Minolta CR-400 colorimeter (Konica Minolta Sensing Inc., Japan), using spectral reflectance included as calibration mode, illuminant D65, and observation angle of $10^{\circ}$. The color variables were measured at four points on the central part of the cut surface of three samples. $\mathrm{L}^{*}, \mathrm{a}^{*}$, and $\mathrm{b}^{*}$ values were determined as indicators of lightness, redness, and yellowness, respectively. Whiteness values were calculated according to CIE values $\left(\mathrm{L}^{*} \mathrm{a} * \mathrm{~b}{ }^{*}\right)$ as described by Park (1994):

$$
\text { Whiteness }=100-\left[\left(100-\mathrm{L}^{*}\right)^{2}+\mathrm{a}^{* 2}+\mathrm{b}^{* 2}\right]^{1 / 2}
$$

\section{Consumer Test}

A pilot consumer test was performed on the burgers elaborated in Experiments 1 and 2. A sensory acceptance test using a 9 point hedonic scale was performed (1 - disliked extremely; 9 - liked extremely) (Meilgaard et al., 2006). The liking of color, aroma, flavor and texture, as well as, overall liking was evaluated by 40 consumers (Franco et al., 2019). Before the consumer test, the burgers were cooked in a hot plate $\left(150^{\circ} \mathrm{C}\right)$, until a temperature of $72^{\circ} \mathrm{C}$. Each burger was cut into four $4 \times 4 \times 2.5 \mathrm{~cm}$ serving samples, wrapped individually in aluminum foil, and served warm to the consumers. Samples were coded with three-digit random numbers and presented to the consumers, balancing the effect of order of presentation and the first-order carry-over effects, according to MacFie et al. (1989). Water at room temperature and salted crackers were provided for palate cleansing. The test was performed in normalized booths under fluorescence lighting and all participants signed an informed consent to participate in the research.

\section{Statistical Analysis}

The experimental design used was completely randomized. The entire experiment was replicated two times in two different days and all analyzes were performed at least in triplicate. The data

TABLE 1 | Formulation (\%) of prebiotic and low-sodium burgers.

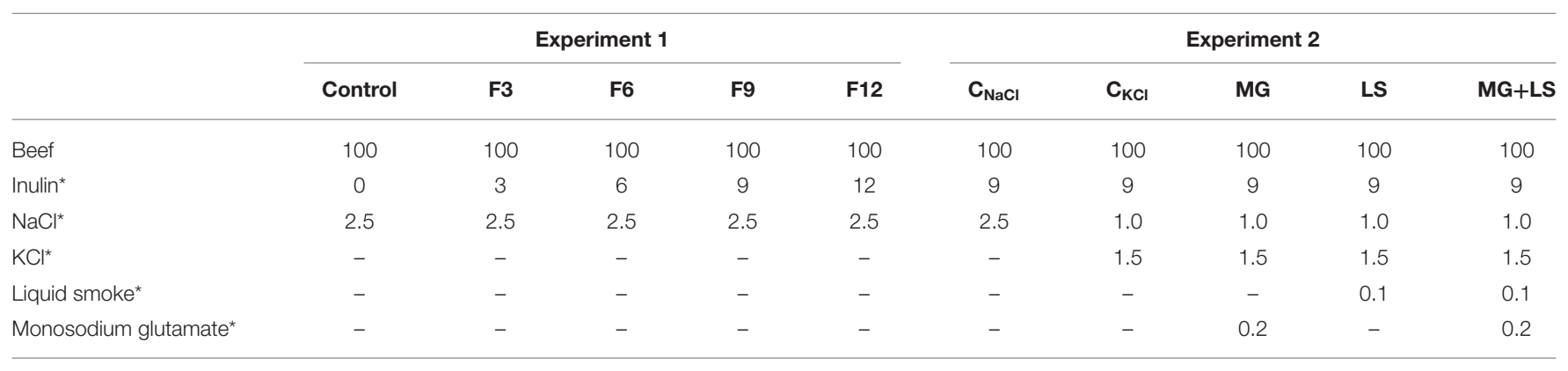

*Added in relation to beef. 
TABLE 2 | Chemical composition (\%) of prebiotic burgers.

\begin{tabular}{lcccc}
\hline & Moisture & Protein & Fat & Ash \\
\hline Control & $63.7 \pm 0.3^{\mathrm{a}}$ & $19.1 \pm 1.7^{\mathrm{a}}$ & $2.5 \pm 0.1^{\mathrm{b}}$ & $6.88 \pm 0.2^{\mathrm{b}}$ \\
F3 & $63.9 \pm 0.1^{\mathrm{a}}$ & $17.5 \pm 0.5^{\mathrm{a}}$ & $2.4 \pm 0.1^{\mathrm{b}}$ & $7.64 \pm 0.1^{\mathrm{ab}}$ \\
F6 & $62.4 \pm 0.1^{\mathrm{b}}$ & $17.4 \pm 1.4^{\mathrm{a}}$ & $2.2 \pm 0.1^{\mathrm{b}}$ & $8.64 \pm 0.1^{\mathrm{a}}$ \\
F9 & $60.8 \pm 0.1^{\mathrm{c}}$ & $18.3 \pm 1.3^{\mathrm{a}}$ & $2.4 \pm 0.2^{\mathrm{b}}$ & $9.05 \pm 0.1^{\mathrm{a}}$ \\
F12 & $57.5 \pm 0.1^{\mathrm{d}}$ & $18.5 \pm 0.6^{\mathrm{a}}$ & $2.5 \pm 1.3^{\mathrm{b}}$ & $9.88 \pm 0.2^{\mathrm{a}}$ \\
\hline
\end{tabular}

*Values represent the mean ( \pm standard deviation). Means followed by the same letter, in the same column, do not show significant difference $(P>0.05)$ by the Tukey test. Control: 0\% inulin; F3: 3\% inulin; F6: 6\% inulin; F9: 9\% inulin; F12: 12\% inulin.

TABLE 3 | Yield and shrinkage of prebiotic burgers.

\begin{tabular}{lcc}
\hline & Yield (\%) & Shrinkage (\%) \\
\hline Control & $61.3 \pm 2.1^{\mathrm{b}}$ & $27.6 \pm 2.28^{\mathrm{a}}$ \\
F3 & $62.1 \pm 2.2^{\mathrm{ab}}$ & $26.2 \pm 2.39^{\mathrm{a}}$ \\
F6 & $64.9 \pm 1.5^{\mathrm{a}}$ & $24.9 \pm 2.07^{\mathrm{b}}$ \\
F9 & $63.6 \pm 1.7^{\mathrm{a}}$ & $23.9 \pm 3.70^{\mathrm{b}}$ \\
F12 & $65.9 \pm 0.7^{\mathrm{a}}$ & $21.2 \pm 2.67^{\mathrm{c}}$ \\
\hline
\end{tabular}

"Values represent the mean ( \pm standard deviation). Means followed by the same letter, in the same column, do not show significant difference $(P>0.05)$ by the Tukey test. Control: 0\% inulin; F3: 3\% inulin; F6: 6\% inulin; F9: 9\% inulin; F12: 12\% inulin.

TABLE 4 | Instrumental color of prebiotic burgers.

\begin{tabular}{lcccc}
\hline & \multicolumn{1}{c}{$\mathbf{L}^{*}$} & $\mathbf{a}^{*}$ & $\mathbf{b}^{*}$ & Whiteness \\
\hline Control & $50.7 \pm 2.5^{\mathrm{b}}$ & $5.5 \pm 0.4^{\mathrm{d}}$ & $8.3 \pm 0.7^{\mathrm{a}}$ & $49.7 \pm 2.4^{\mathrm{b}}$ \\
F3 & $53.2 \pm 2.1^{\mathrm{ab}}$ & $5.8 \pm 0.4^{\mathrm{cd}}$ & $8.6 \pm 0.5^{\mathrm{a}}$ & $52.0 \pm 2.1^{\mathrm{ab}}$ \\
F6 & $52.7 \pm 2.0^{\mathrm{ab}}$ & $6.4 \pm 0.4^{\mathrm{bc}}$ & $8.5 \pm 1.1^{\mathrm{a}}$ & $51.5 \pm 1.5^{\mathrm{ab}}$ \\
F9 & $55.0 \pm 2.1^{\mathrm{a}}$ & $6.9 \pm 0.8^{\mathrm{ab}}$ & $8.8 \pm 0.8^{\mathrm{a}}$ & $53.6 \pm 1.9^{\mathrm{a}}$ \\
F12 & $54.5 \pm 2.2^{\mathrm{a}}$ & $7.5 \pm 0.9^{\mathrm{a}}$ & $9.3 \pm 1.0^{\mathrm{a}}$ & $52.9 \pm 2.1^{\mathrm{a}}$
\end{tabular}

*Values represent the mean ( \pm standard deviation). Means followed by the same letter, in the same column, do not show significant difference $(P>0.05)$ by the Tukey test. Control: O\% inulin; F3: 3\% inulin; F6: 6\% inulin; F9: 9\% inulin; F12: 12\% inulin.

were evaluated through analysis of variance (ANOVA) using the XLStat statistical program. The means were compared by the Tukey test, considering the significance level of $5 \%(P<0.05)$.

\section{RESULTS AND DISCUSSION}

\section{Experiment 1}

The results of the chemical composition of prebiotic burgers are shown in Table 2. The chemical composition of all treatments was in accordance with the parameters required by Brazilian legislation (Brasil, 2000), which establishes a minimum content of $15 \%$ protein and a maximum content of $23 \%$ fat. The addition of $6-12 \%$ inulin decreased the moisture content and increased the ash content of the burgers $(P<0.05)$. No difference $(P<0.05)$ was found in the levels of protein and fat between Control and the reformulated burgers. All treatments can be claimed as "low fat" according to the current European Regulation on nutrition
TABLE 5 | Consumer's acceptance of prebiotic burgers.

\begin{tabular}{lccccc}
\hline & Color & Aroma & Flavor & Texture & Overall liking \\
\hline Control & $7.7 \pm 0.9^{\mathrm{a}}$ & $7.5 \pm 1.2^{\mathrm{a}}$ & $7.7 \pm 1.1^{\mathrm{a}}$ & $7.6 \pm 1.6^{\mathrm{a}}$ & $7.6 \pm 1.1^{\mathrm{a}}$ \\
F3 & $7.6 \pm 1.1^{\mathrm{a}}$ & $7.5 \pm 1.0^{\mathrm{a}}$ & $7.6 \pm 0.8^{\mathrm{a}}$ & $7.3 \pm 1.2^{\mathrm{ab}}$ & $7.5 \pm 0.9^{\mathrm{a}}$ \\
F6 & $7.7 \pm 1.0^{\mathrm{a}}$ & $7.3 \pm 1.2^{\mathrm{a}}$ & $7.5 \pm 0.9^{\mathrm{a}}$ & $7.3 \pm 1.3^{\mathrm{ab}}$ & $7.5 \pm 0.9^{\mathrm{a}}$ \\
F9 & $7.9 \pm 1.1^{\mathrm{a}}$ & $7.3 \pm 1.7^{\mathrm{a}}$ & $7.6 \pm 1.2^{\mathrm{a}}$ & $7.2 \pm 0.9^{\mathrm{ab}}$ & $7.6 \pm 0.9^{\mathrm{a}}$ \\
F12 & $7.7 \pm 1.0^{\mathrm{a}}$ & $7.2 \pm 1.5^{\mathrm{a}}$ & $7.1 \pm 1.6^{\mathrm{a}}$ & $6.8 \pm 1.6^{\mathrm{b}}$ & $6.9 \pm 1.5^{\mathrm{b}}$ \\
\hline
\end{tabular}

*Values represent the mean ( \pm standard deviation). Means followed by the same letter, in the same column, do not show significant difference $(P>0.05)$ by the Tukey test. Control: 0\% inulin; F3: 3\% inulin; F6: 6\% inulin; F9: 9\% inulin; F12: 12\% inulin.

TABLE 6 | Consumer study of prebiotic and low-sodium burgers.

\begin{tabular}{lccccc}
\hline & Color & Aroma & Flavor & Texture & Overall liking \\
\hline $\mathrm{C}_{\mathrm{NaCl}}$ & $7.8 \pm 1.2^{\mathrm{a}}$ & $7.6 \pm 1.4^{\mathrm{a}}$ & $7.6 \pm 1.5^{\mathrm{a}}$ & $7.6 \pm 1.3^{\mathrm{a}}$ & $7.6 \pm 1.3^{\mathrm{b}}$ \\
$\mathrm{C}_{\mathrm{KCl}}$ & $8.0 \pm 0.9^{\mathrm{a}}$ & $7.7 \pm 0.9^{\mathrm{a}}$ & $6.2 \pm 2.5^{\mathrm{b}}$ & $6.2 \pm 2.4^{\mathrm{b}}$ & $6.1 \pm 1.4^{\mathrm{c}}$ \\
$\mathrm{MG}$ & $7.7 \pm 1.0^{\mathrm{a}}$ & $7.7 \pm 0.9^{\mathrm{a}}$ & $7.5 \pm 1.1^{\mathrm{a}}$ & $7.7 \pm 0.9^{\mathrm{a}}$ & $7.6 \pm 0.9^{\mathrm{ab}}$ \\
$\mathrm{LS}$ & $7.9 \pm 0.9^{\mathrm{a}}$ & $7.7 \pm 0.9^{\mathrm{a}}$ & $7.5 \pm 1.1^{\mathrm{a}}$ & $7.5 \pm 1.2^{\mathrm{a}}$ & $7.6 \pm 1.0^{\mathrm{b}}$ \\
$\mathrm{MG}+\mathrm{LS}$ & $8.0 \pm 1.0^{\mathrm{a}}$ & $7.9 \pm 1.2^{\mathrm{a}}$ & $8.1 \pm 1.3^{\mathrm{a}}$ & $8.0 \pm 1.1^{\mathrm{a}}$ & $8.2 \pm 1.1^{\mathrm{a}}$
\end{tabular}

"Values represent the mean ( \pm standard deviation). Means followed by the same letter, in the same column, do not show significant difference $(P>0.05)$ by the Tukey test. $C_{N a C l}$ : 9\% inulin and 2.5\% NaCl; $C_{K C l}$ : 9\% inulin, $1 \% \mathrm{NaCl}$ and $1.5 \% \mathrm{KCl}$ : MG: $9 \%$ inulin, $1 \%$ $\mathrm{NaCl}, 1.5 \% \mathrm{KCl}$ and $0.2 \% \mathrm{MG}$; LS: $9 \%$ inulin, $11 \% \mathrm{NaCl}$ and $1.5 \% \mathrm{KCl}$ and $0.1 \%$ liquid smoke; $M G+$ LS: $9 \%$ inulin, \% NaCl and 1.5\% KCl; MG, 0.2\% MG and 0.1\% liquid smoke.

claims (European Parliament, 2006) because contains no more than $3 \mathrm{~g}$ of fat per $100 \mathrm{~g}$ for solids. In addition, the burgers also can be claimed as "high protein" since that at least $20 \%$ of the energy value of the product $(132.5 \pm 9.3 \mathrm{kcal} / 100 \mathrm{~g})$ is provided by protein.

The percentage of yield and shrinkage of prebiotic burgers are shown in Table 3. The addition of $6-12 \%$ inulin increased the yield and decreased the shrinkage of the burgers as compared to the control $(P<0.05)$. A similar trend was reported by Afshari et al. (2017) and Bis-Souza et al. (2018) who added prebiotic fibers in low-fat beef burgers. The inulin's ability to retain water can be attributed to its long chain of oligosaccharides rich in hydroxyl groups that interact with water by hydrogen bonds. Thus, a crystallized and stable three-dimensional gel network is formed (Barclay et al., 2010; Keenan et al., 2014b).

The instrumental color values of burgers enriched with inulin are shown in Table 4. The addition of inulin (9 and 12\%) increased $(P<0.05)$ the lightness $\left(L^{*}\right)$ of the burgers. The $\mathrm{a}^{*}$ values (redness) were also affected by the addition of inulin. The treatments with addition of $6-12 \%$ inulin (F6, F9, and F12) showed a higher redness than control. The yellowness $\left(b^{*}\right)$ was not affected by the addition of inulin. On the other hand, the results of the Whiteness parameter demonstrated that the addition of 9 and $12 \%$ inulin made the burgers lighter (greater Whiteness). This outcome is in agreement with those observed by Álvarez and Barbut (2013) who noticed that the addition of high levels of fiber affect the instrumental color of meat products. 
The results of consumers' acceptance of prebiotic burgers are summarized in Table 5. Despite the difference observed in the determination of instrumental color, there was no difference in the scores of the attribute "color" among treatments $(P>0.05)$. In addition, the addition of $3-12 \%$ inulin did not impair the "aroma" and "flavor" attributes scores of the burgers. However, the addition of $12 \%$ inulin caused a significant decrease in the "texture" attribute scores compared to the control. This depreciation of the texture was probably responsible for lowering the "overall liking" attribute scores of F12. This result can be attributed to the long length of the inulin chain and its high degree of polymerization (Niness, 1999; Wada et al., 2005). This fact makes inulin less soluble and more viscous, which can negatively affect the texture of reformulated products when added in high levels (Lopez-Lopez et al., 2010). A similar result was noticed by other authors (García et al., 2006; Álvarez and Barbut, 2013; Felisberto et al., 2015) who reported that the addition of levels above $5 \%$ of inulin increased the hardness of meat products.

In summary, the results of Experiment 1 demonstrated that the addition of up to $9 \%$ inulin did not affect consumers' acceptance and improved the yield and shrinkage of the burgers. Thus, the 9\% inulin addition level was chosen for the Experiment 2 , in which, besides to enrich the burgers with prebiotic fibers, a sodium reformulation was performed.

\section{Experiment 2}

The results of consumers' acceptance of prebiotic and lowsodium burgers are shown in Table 6. The scores of the attributes of "color" and "aroma" were not affected by sodium reformulation $(P>0.05) . \mathrm{C}_{\mathrm{KCl}}$ had lower scores than $\mathrm{C}_{\mathrm{NaCl}}$ in the attributes of "flavor," "texture," and "overall liking," demonstrating that the replacement of $60 \%$ of $\mathrm{NaCl}$ by $\mathrm{KCl}$ impaired the sensory quality of the burgers. These results can be attributed mainly to the bitter and astringent taste conferred by $\mathrm{KCl}$ when used in high levels as demonstrated by other studies (Dos Santos et al., 2014, 2015; Santos Alves et al., 2017; Da Silva et al., 2020; Zhang et al., 2020). The MG and LS samples had scores similar $(P>0.05)$ to $\mathrm{C}_{\mathrm{NaCl}}$ in all sensory attributes evaluated. This result demonstrated that the isolated use of MG or LS was able to suppress the sensory defects caused by $\mathrm{KCl}$. Moreover, MG+LS samples presented higher "liking"

\section{REFERENCES}

Afshari, R., Hosseini, H., Khaneghah, A. M., and Khaksar, R. (2017). Physico-chemical properties of functional low-fat beef burgers: fatty acid profile modification. LWT Food Sci. Technol. 78, 325-331. doi: 10.1016/j.lwt.2016.12.054

Álvarez, D., and Barbut, S. (2013). Effect of inulin, $\beta$-Glucan and their mixtures on emulsion stability, color and textural parameters of cooked meat batters. Meat Sci. 94, 320-327. doi: 10.1016/j.meatsci.2013.02.011

AOAC (2005). Official Methods of Analysis of AOAC International, 17th edn. Maryland: AOAC International.

Bakirhan, H., and Karabudak, E. (2021). Effects of inulin on calcium metabolism and bone health. Int. J. Vitam. Nutr. Res. 2021:1-12. doi: 10.1024/0300-9831/a000700 scores than $\mathrm{C}_{\mathrm{NaCl}}$. This outcome demonstrated that $\mathrm{MG}$ and LS had a synergistic effect in improving the sensory quality of low-sodium burgers.

\section{CONCLUSION}

The results of this study indicated that burgers of high technological and sensory quality can be produced by replacing $60 \% \mathrm{NaCl}$ with $\mathrm{KCl}$ and using 9\% inulin, $0.2 \%$ monosodium glutamate and $0.1 \%$ liquid smoke. However, further studies are needed to determine the influence of this reformulation on the shelf life of the burgers.

\section{DATA AVAILABILITY STATEMENT}

The original contributions presented in the study are included in the article/supplementary material, further inquiries can be directed to the corresponding author/s.

\section{ETHICS STATEMENT}

The studies involving human participants were reviewed and approved by Human Research Ethics Committee of the Federal University of Santa Maria. The patients/participants provided their written informed consent to participate in this study.

\section{AUTHOR CONTRIBUTIONS}

BdS: conceptualization, investigation, and writing-original draft. AC: validation, visualization, and writing-review and editing. PC: conceptualization, supervision, project administration, funding acquisition, and writing-original draft. All authors contributed to the article and approved the submitted version.

\section{FUNDING}

Fellowships from National Council for Scientific and Technological Development (CNPq), financial support from CNPq (grant number 425577/2018-0), and Coordination for the Improvement of Higher Education Personnel (CAPES finance code 001) have supported this work. doi: 10.1111/j.1365-2621.1992.tb08037.x

Bis-Souza, C. V., Henck, J. M. M., and Barretto, A. C. S. (2018). Performance of low-fat beef burger with added soluble and insoluble dietary fibers. Food Sci. Technol. 38, 522-529. doi: 10.1590/fst.09217

Brasil (2000). Regulamento Técnico de Identidade e Qualidade de almôndegas, de apresuntado, de fiambre, de Hambúrguer, de kibe, de presunto cozido e de presunto. Diário Oficial da União, Brasília, DF, 03 de agosto de 2000. Ministério da agricultura e Abastecimento. Instrução Normativa n 20 de 31 de Julho de. 
Cappuccio, F. P., Beer, M., and Strazzullo, P. (2019). Population dietary salt reduction and the risk of cardiovascular disease. A scientific statement from the European Salt Action Network. Nutr. Metab. Cardiovasc. Dis. 29, 107-114. doi: 10.1016/j.numecd.2018.11.010

Da Silva, S. L., Lorenzo, J. M., Machado, J. M., Manfio, M., Cichoski, A. J., Fries, L. L. M., et al. (2020). Application of arginine and histidine to improve the technological and sensory properties of low-fat and low-sodium bologna-type sausages produced with high levels of KCl. Meat Sci. 159:107939. doi: 10.1016/j.meatsci.2019.107939

do Amaral, D. S., Cardelle-Cobas, A., do Nascimento, B. M., Monteiro, M. J., Madruga, M. S., and Pintado, M. M. (2015). Development of a low fat fresh pork sausage based on chitosan with health claims: impact on the quality, functionality and shelf-life. Food Funct. 6, 2768-2778. doi: 10.1039/C5FO00303B

Dos Santos, B. A., Bastianello Campagnol, P. C., da Cruz, A. G., Galvão, M. T. E. L., Monteiro, R. A., Wagner, R., et al. (2015). Check all that apply and free listing to describe the sensory characteristics of low sodium dry fermented sausages: comparison with trained panel. Food Res. Int. 76, 725-734. doi: 10.1016/j.foodres.2015.06.035

Dos Santos, B. A., Campagnol, P. C. B., Morgano, M. A., and Pollonio, M. A. R. (2014). Monosodium glutamate, disodium inosinate, disodium guanylate, lysine and taurine improve the sensory quality of fermented cooked sausages with $50 \%$ and $75 \%$ replacement of $\mathrm{NaCl}$ with $\mathrm{KCl}$. Meat Sci. 96, 509-513. doi: $10.1016 /$ j.meatsci.2013.08.024

European Parliament (2006). Regulation (EC) no 1924/2006 of the European Parliament and of the council of 20 December 2006 on Nutrition and Health claims made on Foods. OJEU. L 404/9-L 404/25.

Felisberto, M. H. F., Galvão, M. T. E. L., Picone, C. S. F., Cunha, R. L., and Pollonio, M. A. R. (2015). Effect of prebiotic ingredients on the rheological properties and microstructure of reduced-sodium and low-fat meat emulsions. LWT Food Sci. Tech. 60, 148-155. doi: 10.1016/j.lwt.2014.08.004

Franco, D., Martins, A. J., López-Pedrouso, M., Purriños, L., Cerqueira, M. A., Vicente, A. A., et al. (2019). Strategy towards replacing pork backfat with a linseed oleogel in frankfurter sausages and its evaluation on physicochemical, nutritional, and sensory characteristics. Foods 8:366. doi: $10.3390 /$ foods 8090366

García, M. L., Cáceres, E., and Selgas, M. D. (2006). Effect of inulin on the textural and sensory properties of mortadella, a Spanish cooked meat product. Int. J. Food Sci. Technol. 41, 1207-1215. doi: 10.1111/j.1365-2621.2006.01186.x

Han, M., and Bertram, H. C. (2017). Designing healthier comminuted meat products: effect of dietary fibers on water distribution and texture of a fat-reduced meat model system. Meat Sci. 13, 159-165. doi: 10.1016/j.meatsci.2017.07.001

Henning, S. S. C., Tshalibe, P., and Hoffman, L. C. (2016). Physico-chemical properties of reduced-fat beef species sausage with pork back fat replaced by pineapple dietary fibres and water. LWT Food Sci. Technol. 74, 92-98. doi: 10.1016/j.lwt.2016.07.007

Keenan, D. F., Resconi, V. C., Kerry, J. P., and Hamill, R. M. (2014a). Modelling the influence of inulin as a fat substitute in comminuted meat products on their physico-chemical characteristics and eating quality using a mixture design approach. Meat Sci. 96, 1384-1394. doi: 10.1016/j.meatsci.2013.11.025

Keenan,. D. F., Auty, M. A. E., Doran, L., Kerry, J. P., and Hamill, R. M. (2014b). Investigating the influence of inulin as a fat. Food Struct. 2, 1-13. doi: 10.1016/j.foostr.2014.06.001
Lopez-Lopez, I., Cofrades, S., Yakan, A., Solas, M. T., and Jimenez-Colmenero, F. (2010). Frozen storage characteristics of low-salt and low-fat beef patties as affected by Wakame addition and replacing pork backfat with olive oilin-water emulsion. Food Res. Int. 43, 1244-1254. doi: 10.1016/j.foodres.2010. 03.005

MacFie, H. J., Bratchell, N., Greenhoff, K., and Vallis, L. V. (1989). Designs to balance the effect of order of presentation andfirst-order carry-over effect in halls tests. J. Sens. Stud. 4, 129-148. doi: 10.1111/j.1745-459X.1989.tb00463.x

Meilgaard, M. C., Carr, T., and Civille, G. V. (2006). Sensory Evaluation Tecniques, 4th edn. Boca Raton, FL: CRC Press. doi: 10.1201/b16452

Murphy, E. W., Criner, P. E., and Grey, B. C. (1975). Comparison of methods for calculating retentions of nutrients in cooked foods. J. Agric. Food Chem. 23, 1153-1157. doi: 10.1021/jf60202a021

Niness, K. R. (1999). Inulin and oligofructose: what are they? J. Nutr. 129, 1402s-1406s. doi: 10.1093/jn/129.7.1402S

Park, J. W. (1994). Functional protein additives in surimi gels. J. Food Sci. 59, 525-527. doi: 10.1111/j.1365-2621.1994.tb05554.x

Pateiro, M., Munekata, P. E. S., Cittadini, A., Domínguez, E., and Lorenzo, J. M. (2021). Metallic-based salt substitutes to reduce sodium content in meat products. Curr. Opin. Food Sci. 40, 21-31. doi: 10.1016/j.cofs.2020.10.029

Saad, S. M. I., Cruz, A. G., and Faria, J. A. F. (2011). Probióticos e Prebióticos em Alimentos: Fundamentos e Aplicações Tecnológicas. São Paulo: Editora Varela.

Saldaña, E., Merlo, T. C., Patinho, I., Rios-Mera, J. D., Contreras-Castillo, C. J., and Selani, M. M. (2021). Use of sensory science for the development of healthier processed meat products: a critical opinion. Curr. Opin. Food Sci. 40, 13-19. doi: $10.1016 /$ j.cofs.2020.04.012

Santos Alves, L. A. A., Lorenzo, J. M., Goncalves, C. A. A., dos Santos, B. A., Heck, R. T., Cichoski, A. J., et al. (2017). Impact of lysine and liquid smoke as flavor enhancers on the quality of low-fat bologna-type sausages with $50 \%$ replacement of $\mathrm{NaCl}$ by $\mathrm{KCl}$. Meat Sci. 123, 50-56. doi: 10.1016/j.meatsci.2016.09.001

Wada, T., Sugatani, J., Terada, E., Ohguchi, M., and Miwa, M. (2005). Physicochemical characterization and biological effects of inulin enzymatically synthesized from sucrose. J. Agric. Food Chem. 53, 1246-1253. doi: 10.1021/jf048711u

Wan, X., Guo, H., Liang, Y., Zhou, C., Liu, Z., Li, K., et al. (2020). The physiological functions and pharmaceutical applications of inulin: a review. Carbohydr. Polym. 246:116589. doi: 10.1016/j.carbpol.2020.116589

Zhang, X., Yang, J., Gao, H., Zhao, Y., Wang, J., and Wang, S. (2020). Substituting sodium by various metal ions affects the cathepsins activity and proteolysis in dry-cured pork butts. Meat Sci. 166:108132. doi: 10.1016/j.meatsci.2020. 108132

Conflict of Interest: The authors declare that the research was conducted in the absence of any commercial or financial relationships that could be construed as a potential conflict of interest.

Copyright (C) 2021 dos Santos, Cichoski and Campagnol. This is an open-access article distributed under the terms of the Creative Commons Attribution License (CC BY). The use, distribution or reproduction in other forums is permitted, provided the original author(s) and the copyright owner(s) are credited and that the original publication in this journal is cited, in accordance with accepted academic practice. No use, distribution or reproduction is permitted which does not comply with these terms. 